\title{
Residential Densification for Positive Energy Districts
}

\author{
James Bambara ${ }^{1 *}$, Andreas K. Athienitis ${ }^{2}$ and Ursula Eicker ${ }^{3}$ \\ ${ }^{1}$ Centre for Zero Energy Building Studies and CERC Next-Generation Cities, Concordia University, Montreal, QC, Canada, \\ ${ }^{2}$ Centre for Zero Energy Building Studies, Concordia University, Montreal, QC, Canada, ${ }^{3}$ CERC Next-Generation Cities, \\ Concordia University, Montreal, QC, Canada
}

OPEN ACCESS

Edited by:

Edgar Liu,

University of New South

Wales, Australia

Reviewed by:

Riccardo Paolini,

University of New South

Wales, Australia

Jiying Liu,

Shandong Jianzhu University, China

*Correspondence:

James Bambara

j_bamba@encs.concordia.ca

Specialty section: This article was submitted to

Urban Energy End-Use,

a section of the journa

Frontiers in Sustainable Cities

Received: 18 November 2020

Accepted: 11 January 2021

Published: 04 February 2021

Citation:

Bambara J, Athienitis AK and Eicker U (2021) Residential Densification for

Positive Energy Districts.

Front. Sustain. Cities 3:630973. doi: 10.3389 /frsc. 2021.630973
The energy footprint of houses can be reduced by replacing the aging stock with higher density and more energy efficient homes equipped with on-site renewable energy production. In this study, a "double density" simulation scenario is considered where each existing detached house in a community is replaced with two houses of equal living area on the same land lot. The new houses were assumed to be equipped with several energy efficiency measures (envelope, HVAC, and domestic hot water) and a building-integrated photovoltaic (BIPV) roof. The TRNSYS software was used to simulate the annual energy performance of the buildings in Montreal, Québec, Canada $\left(45.5^{\circ} \mathrm{N}\right)$. It was found that the two new houses, which can accommodate twice the number of people on the same land lot, consumed 30\% less energy than the existing house. Individually, each of the new houses required 65\% less electricity than the existing house (reduced from 22,560

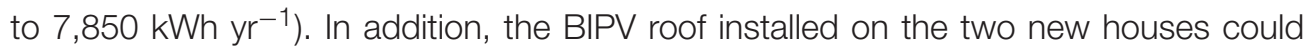
generate nearly three times more electricity $\left(44,000 \mathrm{kWh} \mathrm{yr}^{-1}\right)$ than they consumed $\left(15,700 \mathrm{kWh} \mathrm{yr}^{-1}\right)$. Annually, nearly half (44\%) of the house's electricity can be directly supplied by the BIPV system. A significant portion of the annual solar electricity generation (84\%), which cannot be directly utilized by the houses, can be stored on-site for later use to increase self-consumption (e.g., power-to-thermal energy or charging electric vehicles) or could be exported to the grid to support decarbonization elsewhere (e.g., production of hydrogen fuel for transportation). The combined effect of energy efficient construction and on-site renewable energy production would enable occupants to shift from consuming $5,640 \mathrm{kWh} \mathrm{yr}^{-1}$ to producing $3,540 \mathrm{kWh} \mathrm{yr}^{-1}$. Residential densification can significantly contribute toward retrofitting existing communities into resilient positive energy districts.

Keywords: residential redevelopment, densification, energy efficiency, building-integrated photovoltaics, positive energy building, energy flexibility, resilience, decarbonization

\section{INTRODUCTION}

As more and more people move to cities, there will be a need for either densification or urban expansion. Densification is a possible way to achieve more compact cities, combat sprawl, and improve urban sustainability. Meanwhile, aging buildings that need to be renovated or replaced create an opportunity for modern designs that can reduce overall energy use while improving quality of life. In Canada, 54\% of the buildings were built before 1979, many of which will need to be upgraded in the near future (Natural Resources Canada, 2020). This aging building 
stock can either undergo a deep retrofit (i.e., same footprint, structure is kept), a deep retrofit combined with extensions (adding floors or footprint area) or be demolished/recycled and rebuilt. Rebuilds and deep retrofits with extensions offer the advantages of densification, whereby more occupants can inhabit the same land area. This can lead to energy savings for building operation and transportation (reduced travel distances and associated congestion/pollution) (O'Brien et al., 2009).

Both retrofits and rebuilds lower energy consumption (and the associated environmental pollution) due to the improved performance of a modern building envelope and HVAC system, amongst others. Several empirical and numerical studies have been performed to quantify the energy and economic potential for improved designs such as thermal insulation (Mohamed, 2020), windows (Aste et al., 2018) and their shading system (Kunwar, 2018), use of heat pump for heating and cooling (Alshehri et al., 2019; Liu et al., 2019) and domestic hot water heating (Minetto et al., 2016), energy recovery ventilation (Psimopoulos et al., 2019), high efficiency lighting and appliances (Fantozzi et al., 2017; Heidari and Patel, 2020) and low flow faucets (Englart and Jedlikowski, 2019). Numerical studies may employ custom models and often commercially available energy modeling software (e.g., TRNSYS, eQUEST, EnergyPlus) to predict the energy consumption of buildings (Crawley et al., 2008; Han et al., 2014). A simulation study in Sweden showed that stepby-step renovations on their aging houses can reduce energy use by up to $75 \%$ (Ekström and Blomsterberg, 2016). Other studies have focused on optimizing the geometry and orientation of buildings to reduce their energy consumption (Capozzoli et al., 2009; Granadeiro et al., 2013; Touloupaki and Theodosiou, 2017).

The production of renewable energy on-site using photovoltaics (PV) can further reduce energy use and even lead to net-zero or positive energy buildings (produce more energy than they consume on an annual basis), particularly for detached houses which have a relatively large well-exposed surface area for solar energy capture compared to their energy use (Mohajeri et al., 2016). Dramatic cost reductions of PV technology combined with incentives such as feed-in-tariffs have helped to accelerate their deployment. Meanwhile, their efficiency has been increasing and commercially available monocrystalline PV modules can now convert up to $21 \%$ of the incident solar energy into electricity (Jinko Solar, 2020). Energy generation depends mainly on the geometry and orientation of the PV system and to a lesser degree the panel's surface temperature. Hachem et al. (2011) presented a methodology for investigating the impact of design parameters for two-story houses in different neighborhood layouts, on solar energy utilization potential. As demonstrated through the construction of the "Ecoterra" near net zero energy demonstration house in Canada, building-integration of PV technology can further reduce costs by substituting the need for conventional building materials (Bucking et al., 2010). The electrical efficiency and durability can be improved by cooling the PV panels (PV/thermal system), where the heat that would otherwise be wasted can be recovered for use within the building (Athienitis et al., 2011).

In contrast to the number of studies on energy use and solar potential, there are few studies focusing on the relationship between the density and building energy performance (Steemers, 2003; Holden and Norland, 2005; Brown and Logan, 2008; Kontokosta, 2012; Quan, 2016). O’Brien et al. (2009) performed a numerical simulation to compare the energy performance of three housing types in Toronto (detached homes, townhouses, and multi-story residential). The study found higher density in terms of dwelling unit area has both lower building energy use per occupant and per floor area. The study also reports that the solar potential decreases as the density increases, and that there is possibly an optimal density in terms of solar potential. Another study examining Toronto neighborhoods also concluded that higher density in terms of dwelling unit per unit area has lower building energy use per occupant, but slightly higher building energy use per floor area (Norman et al., 2006).

From an extensive literature review, there are a lack of studies that evaluate the impact of different housing densities on energy performance at the land lot scale. Densification of detached homes may consist of replacing aging homes with two new homes (and possible more depending on the land lot size) capable of housing more occupants on the same land lot. These residential rebuilds can offer similar characteristics as their aging counterparts (e.g., similar living area and private outdoor space) while reducing the energy use per occupant. The goal of this study is to compare the energy performance of a typical aging home that was built in the 1970 s with a densification scenario where two energy efficient homes of equal living area and equipped with a building-integrated PV (BIPV) roof are built on the same land lot located in the suburbs of Montreal, Québec, Canada $\left(45.5^{\circ} \mathrm{N}\right.$, mid-latitude, 4,457 heating degree-days).

\section{ENERGY ANALYSIS}

The purpose of this study is to compare the energy performance (consumption and generation) of an existing house with that of two energy efficient homes equipped with BIPV that are built on the same land lot. An energy model will be created for each of the houses and annual energy simulations will be performed to quantify their energy performance.

\section{House Characteristics}

The geometry of the existing house reflects typical construction of the 1970s in a Montreal suburb (Figure 1A). Figure 1B depicts a possible geometry for the case where two new houses are built on the same land lot that previously had one house.

A major objective of this study is to quantify the energy savings potential that can be achieved by replacing aging detached homes with two homes of similar living area. This "double density" scenario would house twice the number of people on the same land area. The new houses are assumed to be built to the highest standards of energy efficiency and will consume significantly less energy than the aging stock. In addition, the new houses will be equipped with a BIPV roof to produce electricity on-site and offset some or all their electricity use.

The existing single-story house is comprised of a basement and a main living floor above it, with a slab on grade garage connected to it (Figure 2A). The new houses are designed to have the same living area (typically excludes basement and garage) 

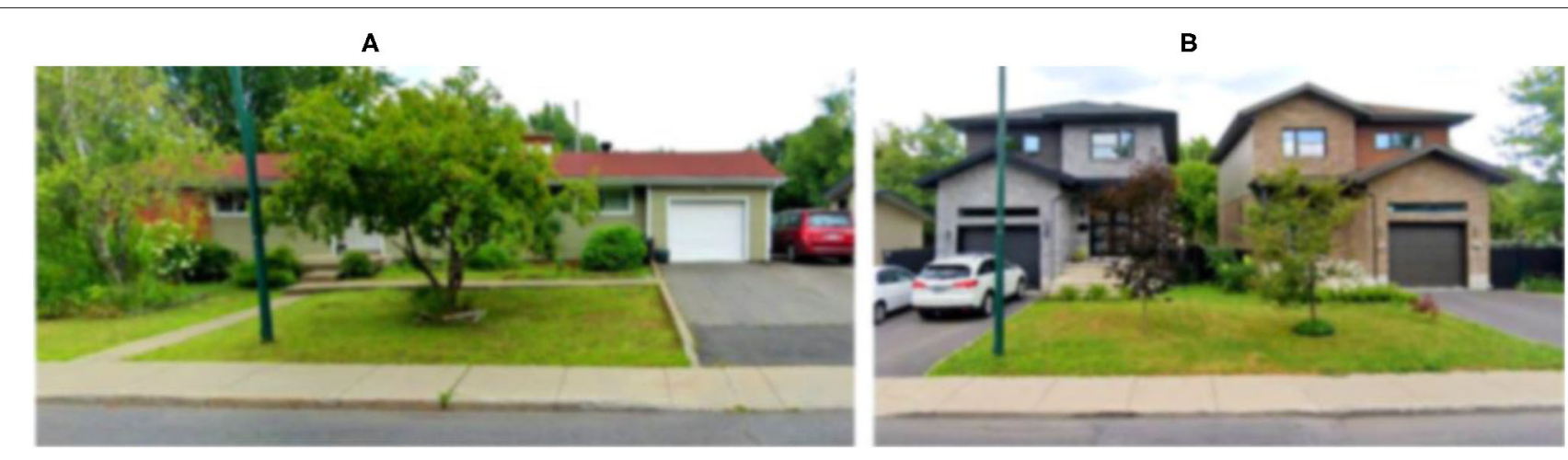

FIGURE 1 | Photos depicting two houses: (A) single story existing house; (B) two two-story houses built on the same land lot (google maps).

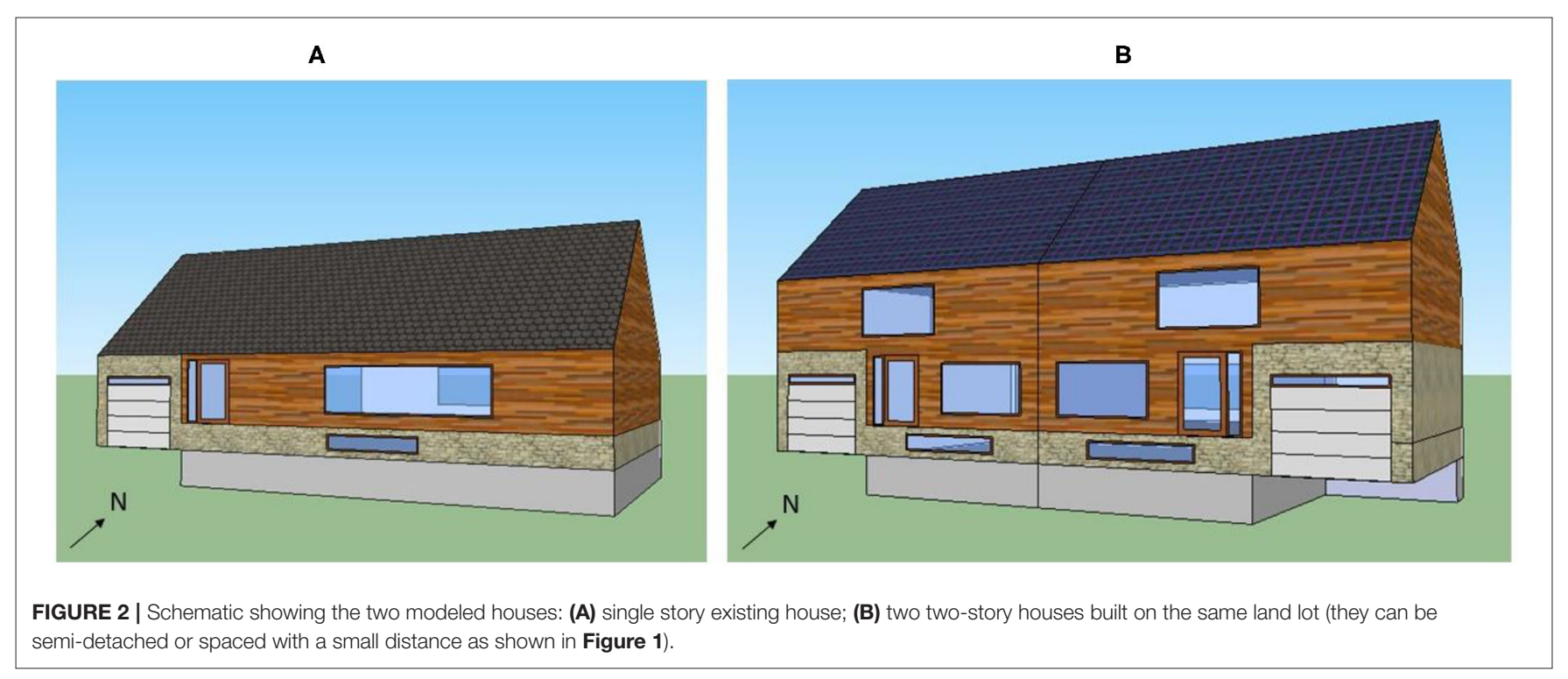

as their existing counterparts. In order to build two houses on the same land lot $\left(\sim 850 \mathrm{~m}^{2}\right)$ while maximizing available outdoor space, the new homes will have two stories. Similarly, the new houses will have an attached garage and a basement. Due to practical geometrical constraints and the required smaller footprint of the new houses, the basement area was reduced by $40 \%$ compared to the existing house. This study considers the case where the two new homes are attached to reduce both the amount of construction materials/labor and operation energy consumption (Figure 2B). The total footprint of the existing house is $166.8 \mathrm{~m}^{2}$ and building two houses required $32 \%$ more land area (the footprint of each of the new houses is $34 \%$ less than existing house). Table 1 provides the geometry details of the existing and new houses.

Table 2 provides an overview of the energy efficiency measures that were considered in the study. They are related to the space and domestic hot water (DHW) heating, space cooling, building envelope, and ventilation. Due to improved construction, the new house is more airtight than the existing house and so ventilation is required to supply enough fresh air to the occupants. Energy recovery ventilation is used to recover thermal energy from the exhausted ventilation air. It is assumed that the plug loads are the same for the existing and new houses because it is desired to focus on efficiency gains that can be achieved from an improved envelope, HVAC, and DHW design. The most common energy efficiency measures for homes that operate using electricity were selected for this study. An economic study such as life cycle cost analysis would be needed to evaluate whether the selected energy efficiency measures and potentially others satisfy the developer's investment decision criteria. In addition, the roof of the new houses is equipped a BIPV system to generate energy on-site.

\section{Energy Modeling and Simulation}

The TRNSYS 17.2 software was selected for the transient simulation of the house climate (Klein et al., 2014). Type 56 multizone building model was used to create the building energy model (TRNSYS 17, 2005). Annual energy simulations of the model are performed to obtain the energy performance (consumption and generation) of the existing and the new 
TABLE 1 | Details of the house geometry.

\begin{tabular}{lcc}
\hline & Existing & New \\
\hline Garage $\left(\mathrm{m}^{2}\right)$ & 26.8 & 26.8 \\
Basement $\left(\mathrm{m}^{2}\right)$ & 140 & 83.4 \\
First floor $\left(\mathrm{m}^{2}\right)$ & 140 & 56.6 \\
Second floor $\left(\mathrm{m}^{2}\right)$ & - & 83.4 \\
Total living area $\left(\mathrm{m}^{2}\right)$ & 140 & 140 \\
Garage height $(\mathrm{m})$ & 3.2 & 3.2 \\
Basement height $(\mathrm{m})$ & 2.1 & 2.1 \\
Basement height above ground & 1.2 & 1.2 \\
First and second floor height $(\mathrm{m})$ & 2.3 & 2.3 \\
Basement window area $\left(\right.$ south and north) $\left(\mathrm{m}^{2}\right)$ & 1.5 & 1.5 \\
First floor window area $\left(\right.$ south and north) $\left(\mathrm{m}^{2}\right)$ & 8 & 4 \\
Second floor window area $\left(\right.$ south and north) $\left(\mathrm{m}^{2}\right)$ & - & 4 \\
Front door area (south) $\left(\mathrm{m}^{2}\right)$ & 3.5 & 3.5 \\
Garage door area (south) $\left(\mathrm{m}^{2}\right)$ & 6.7 & 6.7 \\
Sliding door area (north) $\left(\mathrm{m}^{2}\right)$ & 3.7 & 3.7 \\
\hline
\end{tabular}

TABLE 2 | Energy efficiency measures considered for the modeled houses.

\begin{tabular}{|c|c|c|}
\hline & Existing & New \\
\hline Space heating & Electric resistance & $\begin{array}{l}\text { Electric reversible heat } \\
\text { pump }\end{array}$ \\
\hline Space cooling & AC unit & $\begin{array}{l}\text { Electric reversible heat } \\
\text { pump }\end{array}$ \\
\hline DHW heating & Electric resistance & $\begin{array}{l}\text { Electric } \mathrm{CO}_{2} \text { heat } \\
\text { pump }\end{array}$ \\
\hline DHW consumption & Standard faucets & Low flow faucets \\
\hline Thermal insulation & Standard (1970's) & $\begin{array}{l}50 \% \text { higher than } \\
\text { existing (Novoclimat } \\
\text { standards) }\end{array}$ \\
\hline Windows & Double glazed air & $\begin{array}{l}\text { Double glazed argon } \\
\text { low-e, } 50 \% \text { higher } \\
\text { frame insulation }\end{array}$ \\
\hline Movable shades & No & Yes \\
\hline Infiltration rate & Loose construction & Airtight construction \\
\hline Ventilation & None & $\begin{array}{l}\text { Energy recovery } \\
\text { ventilation }\end{array}$ \\
\hline
\end{tabular}

houses. Each house model consists of four-to-five thermal zones: garage, basement, living floor (one zone for the existing house and one zone for each story of the new houses), and a ventilated attic. Due to the geometry, there are more than one thermal zones for the basement and two floors of the new house.

\section{Energy Modeling Key Assumptions}

The details, parameter values and assumptions for the building modeling are presented below and given in Table 3.

\section{Weather Data}

A typical meteorological year (TMY) weather file for Montreal, Québec, Canada $\left(45.5^{\circ} \mathrm{N}\right)$ was used to run the simulations and obtain the energy performance over a one-year period. Type 15 calculates the sky temperature for longwave radiation calculations (TRNSYS 17, 2014). The ground surface temperature is assumed to be the same as the exterior air temperature. The diffuse solar radiation component is calculated using the anisotropic diffuse model by Perez et al. (1988). A simulation timestep $(\Delta t)$ of $1 \mathrm{~h}$ was selected. The energy model was simulated for 455 days, with the first 3 months of results ignored to eliminate the initial transient effects associated with the soil.

\section{Conduction}

Type 56 uses the ASHRAE transfer function method to solve the transient conduction heat transfer through opaque envelope components (Stephenson and Mitalas, 1971; Mitalas and Arseneault, 1972). Thermal energy storage is neglected for heat conduction through windows, doors, and the movable shades.

\section{Convection}

Type 56 provides internal calculation of natural convective heat transfer coefficients (CHTC) using turbulent natural CHTC correlations developed by McAdams (1959). The exterior CHTC is mainly a function of wind speed and an empirical correlation by McAdams (1959) was selected in the model. Moreover, the model assumes that the air is well-mixed inside each thermal zone.

\section{Shortwave Radiation}

Type 56 enables detailed computations for radiation distribution, including multi-reflection and solar radiation leaving the zone through the windows, whereby beam and diffuse components are considered separately. A detailed calculation for distributing the primary solar direct radiation entering the zone is achieved using geometric distribution (TRNSYS 17, 2005). For a detailed treatment of shortwave diffuse radiation, the TRNSYS radiation model applies Gebhart factors (Gebhart, 1961, 1971).

\section{Longwave Radiation}

Type 56 enables detailed computations for longwave radiation heat transfer between inside surfaces and from exterior surfaces to the ground and sky.

\section{Ventilation}

The existing house does not have mechanical ventilation as sufficient fresh air is provided by natural air infiltration. For the new houses, mechanical ventilation with sensible energy recovery is provided according to ASHRAE (2019) for a threebedroom house. It is assumed that $60 \%$ of the ventilation air is provided to the first floor and the rest to the second floor. The electricity consumed to operate the energy recovery ventilation (ERV) system is included in the plug loads. No ventilation is provided in the basement and garage. Air exchange was neglected between the thermal zones of the basement and two floors of the new house. Ventilation air is assumed to be provided to the largest thermal zone on each floor.

\section{Internal Gains}

The internal gains are applied to the house's living area and specified by NRCC (National Research Council of Canada) (2015) and given in Table 4. For the two-story houses, the total gains for a house are split with $2 / 3^{\text {rd }}$ to the main floor and 
TABLE 3 | Parameter values of different materials/components used in the house model (values for the new house are in parenthesis).

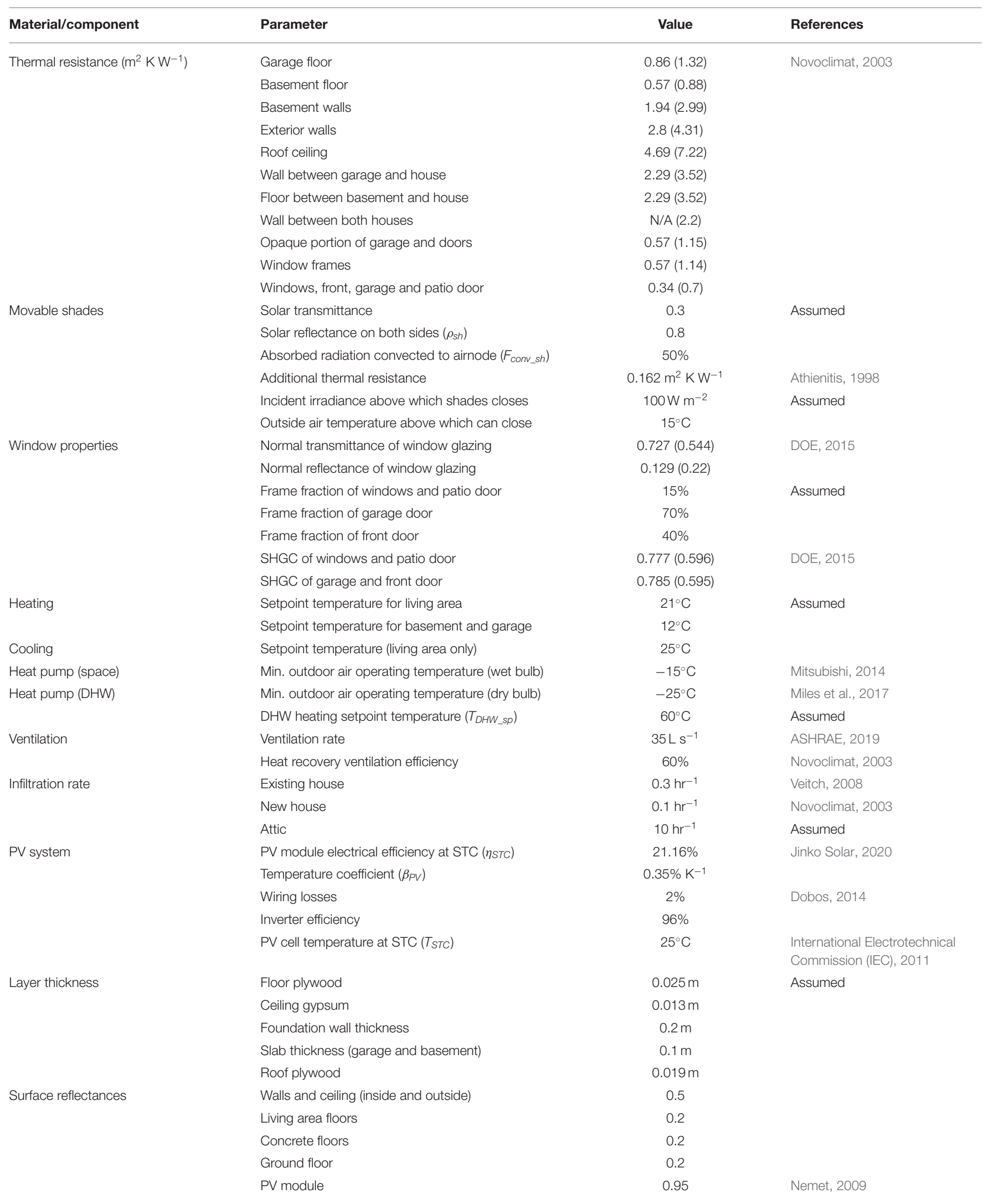


TABLE 3 | Continued

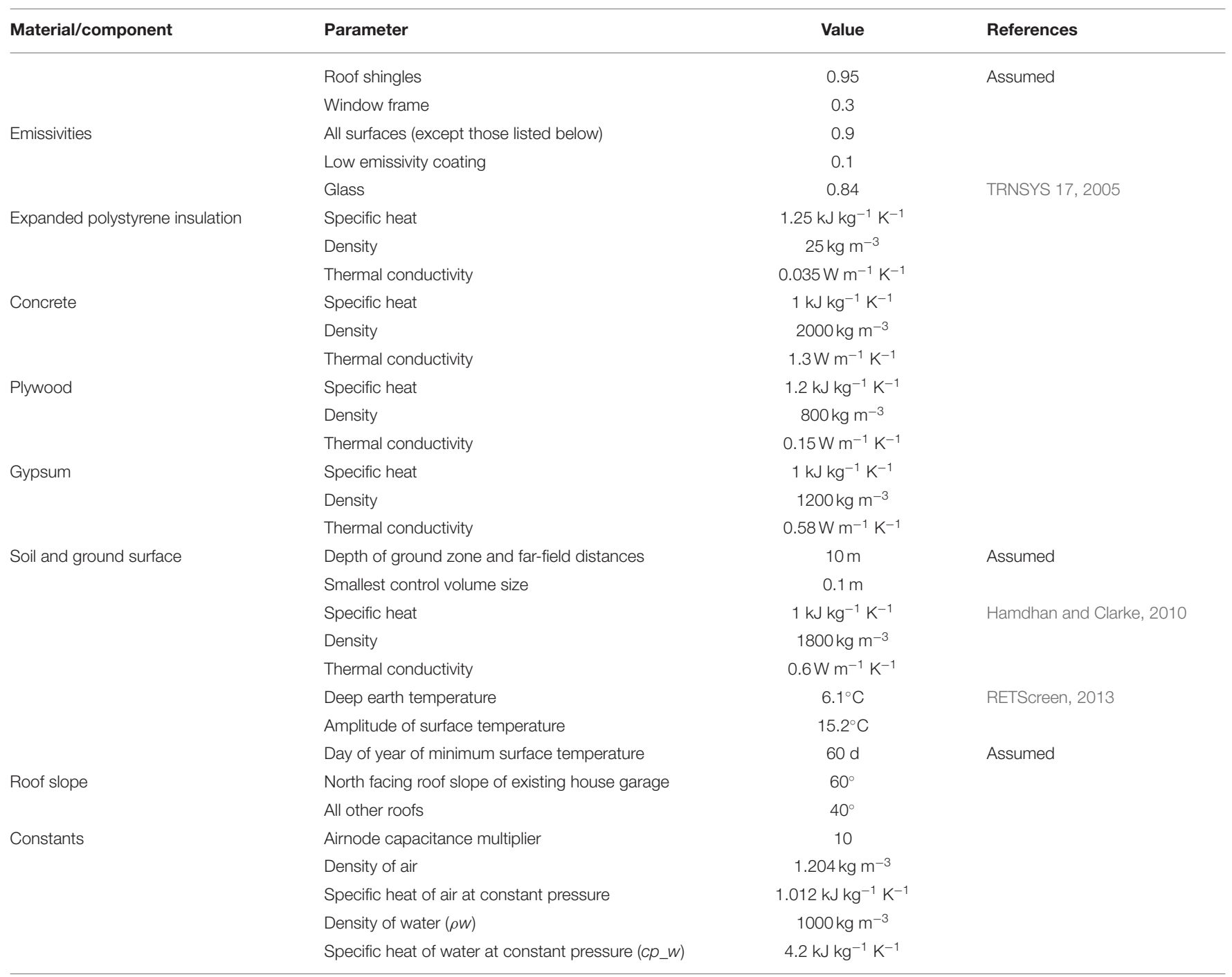

$1 / 3^{\text {rd }}$ to the second floor. The garage, basement and attic are assumed to not have internal loads. All internal gains are assumed to be convected to the airnode. Only sensible internal gains are considered and latent effects such as occupant transpiration are ignored.

\section{Plug Loads}

A fraction of internal gains are plug loads. It was assumed that $50 \%$ of the internal gains are plug loads which translates to 4,088 $\mathrm{kWh} \mathrm{yr}^{-1}$ and in agreement with values provided in the literature (George, 2016). Table 4 provides the plug load schedule.

\section{Ground Heat Transfer}

Type 1244 was selected because it enables detailed heat transfer calculations (using 3D finite difference) between the Type 56 multi-zone building model and the ground surface by creating a geometrical "map" (Personnel communications with TESS Technical Support Team, 2017). A user defined volume of soil is considered for ground heat transfer and divided into control volumes that are assumed to be cubic in shape so there are six unique heat transfers to analyze per control volume. The dimensions of the control volumes were multiplied by a factor of two as they expanded away from the perimeter of the house airnodes. The boundary conditions are specified as adiabatic.

\section{Solar Electricity Generation}

The roof of the new house is equipped with BIPV system comprised of monocrystalline PV modules (Jinko Solar, 2020) and an inverter. Two cases will be considered for assessing solar energy capture potential: PV on the south (facing the street) and north facing roof, and PV on the east and west facing roof when the house orientation is rotated by $90^{\circ}$ counterclockwise. To calculate temperature-dependent PV electricity generation, a simplified method was used to estimate the PV surface temperature. The BIPV was modeled as a layer of plywood (which separates the exterior air and ventilated attic) with solar absorptance and emittance values corresponding to a typical PV 
TABLE 4 | Internal gains, plug loads, and DHW consumption schedules.

\begin{tabular}{|c|c|c|c|}
\hline Hour of the day & Internal gains (W) & Plug loads (W) & DHW use $\left(\mathrm{L} \mathrm{hr}^{-1}\right)$ \\
\hline 0 & 786.1 & 393.1 & 0 \\
\hline 1 & 551.9 & 276.0 & 0 \\
\hline 2 & 548.9 & 274.4 & 0 \\
\hline 3 & 523.1 & 261.5 & 0 \\
\hline 4 & 521.1 & 260.6 & 0 \\
\hline 5 & 546.9 & 273.5 & 0 \\
\hline 6 & 633.9 & 316.9 & 0 \\
\hline 7 & 726.1 & 363.1 & 3.1 \\
\hline 8 & 846.9 & 423.5 & 12.4 \\
\hline 9 & 880.0 & 440.0 & 18.7 \\
\hline 10 & 906.1 & 453.1 & 34.2 \\
\hline 11 & 986.1 & 493.1 & 17.1 \\
\hline 12 & 991.9 & 496.0 & 4.7 \\
\hline 13 & 933.9 & 466.9 & 1.6 \\
\hline 14 & 898.1 & 449.0 & 3.1 \\
\hline 15 & 911.1 & 455.6 & 7.8 \\
\hline 16 & 923.9 & 461.9 & 14 \\
\hline 17 & 1088.9 & 544.4 & 9.3 \\
\hline 18 & 1410.0 & 705.0 & 9.3 \\
\hline 19 & 1588.1 & 794.0 & 3.1 \\
\hline 20 & 1568.1 & 784.0 & 1.6 \\
\hline 21 & 1483.1 & 741.5 & 0 \\
\hline 22 & 1193.9 & 596.9 & 0 \\
\hline 23 & 951.9 & 476.0 & 0 \\
\hline
\end{tabular}

surface. The energy produced by the PV is taken into account for the surface energy balance.

The rate of electricity generation from the BIPV roof ( $E_{p v}$ in W) is estimated using (Skoplaki and Palyvos, 2009):

$$
\begin{array}{r}
E_{p v}=I_{p v_{-} s o} \cdot A \cdot \eta_{S T C} \\
\cdot\left(1-\beta_{p v} \cdot\left[T_{p v \_s o}-T_{S T C}\right]\right) \cdot\left(1-L_{w}\right) \cdot \eta_{i n v}
\end{array}
$$

where

$I_{p v_{s} s o}$ is solar radiation incident on the outside PV surface $\left(\mathrm{W} \mathrm{m}^{-2}\right.$ )

$A$ is the PV area on the roof $\left(\mathrm{m}^{2}\right)$

$\eta_{S T C}$ is the electrical efficiency of the PV module at STC (\%)

$\beta_{P V}$ is the PV module temperature coefficient $\left(\% \mathrm{~K}^{-1}\right)$

$T_{p v_{-} s o}$ is the temperature of outside surface temperature of the PV cells $\left({ }^{\circ} \mathrm{C}\right)$

$T_{S T C}$ is the PV cells temperature at STC $\left({ }^{\circ} \mathrm{C}\right)$

$L_{w}$ is the wiring losses (\%)

$\eta_{i n v}$ is the DC/AC inverter efficiency (\%).

The effect of solar incidence angle on electricity generation is not considered. The annual electric energy generated by the STPV cladding $\left(E_{p v \_y r}\right.$ in $\left.\mathrm{kWh} \mathrm{yr}^{-1}\right)$ is determined from:

$$
E_{p v \_y r}=\sum_{\Delta t=0}^{\frac{365 \cdot 24}{\Delta t}}\left[\frac{\Delta t \cdot\left(E_{p v}\right)}{10^{3}}\right]
$$

where the factor $10^{3}$ serves to convert units $\mathrm{W}$ to $\mathrm{kW}$.

\section{Envelope Construction}

The level of thermal insulation for the new houses is based on Novoclimat (2003), an advanced standard for energy efficient construction in Canada. A reduction factor was applied to estimate the thermal insulation level in the existing house (see section Model Plausibility Check). The details for the envelope design are presented below:

\section{Walls}

All the walls are modeled as a single layer of expanded polystyrene (EPS).

\section{Basement Walls}

The foundation walls of the new house consist of concrete with exterior EPS insulation. The foundation walls of new house are made of insulated concrete form comprised of concrete with EPS insulation on each side.

\section{Floor and Ceiling}

Inter-stories are modeled as a floor made of plywood and a ceiling finished with gypsum. The garage and basement floor consist of a slab on grade with EPS insulation beneath.

\section{Wall Separating New Houses}

The wall that separates the two new houses is assumed to insulated using EPS. If the houses are separated by a small distance as shown in Figure 1, this is not expected to significantly affect heating load.

\section{Roof}

The roof slope is identical except for the north facing slope of the existing house's garage. The exterior finish is modeled as a layer of plywood with an absorptance and emittance that represents dark shingles or PV panels.

\section{Windows}

The windows and doors consist of a glazed portion and a frame portion. The glazed fraction on each facade orientation is the same for the existing and new houses. The glazing types for the existing house are double glazed air filled (for the windows and patio door: $2.5 \mathrm{~mm}$ glass, $12.7 \mathrm{~mm}$ airspace, $2.5 \mathrm{~mm}$ glass; for the custom windows: $3 \mathrm{~mm}$ glass, $12.7 \mathrm{~mm}$ airspace, $3 \mathrm{~mm}$ ) and for the new houses double-glazed argon filled with a low emissivity coating (for the windows and patio door: $3 \mathrm{~mm}$ glass, $12.7 \mathrm{~mm}$ airspace, $2.5 \mathrm{~mm}$ glass; for the custom windows: $3 \mathrm{~mm}$ glass, $12.7 \mathrm{~mm}$ airspace, $3 \mathrm{~mm}$ ). Custom windows were created for the main door and the garage because their frame area is large compared to the glazed portion. Window 7.3 was used to calculate the overall thermal and incidence angle dependent optical properties of the custom windows (DOE, 2015). The edge heat transfer effects and energy storage in glazing materials and framing is neglected.

\section{Movable Shades}

A single motorized movable shade $(s h)$ is installed on the inside surface of all windows (excludes garage, front, and patio door) to 
reduce the cooling load. The solar radiation that is absorbed on the shade and convected to an airnode $\left(Q_{s h}\right.$ in $\left.\mathrm{W}\right)$ is given by:

$$
Q_{s h}=I_{s h} \cdot\left(1-\rho_{s h}\right) \cdot F_{c o n v \_s h}
$$

where

$I_{s h}$ is solar radiation incident on the movable shade $\left(\mathrm{W} \mathrm{m}^{-2}\right)$ $\rho_{s h}$ is solar reflectance of the movable shade (\%)

$F_{\text {conv_sh }}$ is the fraction of absorbed solar radiation convected to the air (\%).

\section{Capacitance Multiplier}

A thermal capacitance multiplier was specified to account for interior furnishings.

\section{Thermal Energy Consumption}

The output of the TRNSYS simulation provides the heating $\left(Q_{\text {heat }}\right.$ in $\left.\mathrm{kJ} \mathrm{hr}^{-1}\right)$ and cooling $\left(Q_{\text {cool }}\right.$ in $\left.\mathrm{kJ} \mathrm{hr}^{-1}\right)$ power at each timestep that is required to maintain the desired setpoint temperature.

The annual thermal energy consumption for heating ( $Q_{\text {heat_yr }}$

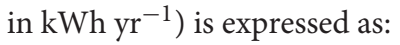

$$
Q_{\text {heat_yr }}=\sum_{\Delta t=0}^{\frac{365 \cdot 24}{\Delta t}}\left(\frac{Q_{\text {heat }} \cdot \Delta t}{3600}\right)
$$

where the factor 3600 serves to convert units hr to s.

Similarly, the annual thermal energy consumption for cooling

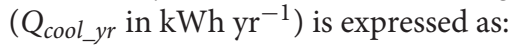

$$
Q_{\text {cool_yr }}=\sum_{\Delta t=0}^{\frac{365 \cdot 24}{\Delta t}}\left(\frac{Q_{\text {cool }} \cdot \Delta t}{3600}\right)
$$

\section{Electricity Use for Heating and Cooling}

An electric air conditioner (AC) unit is used to cool in the existing house and an electric reversible heat pump provides heating and cooling in the new houses. It is assumed that the coefficient of performance $(C O P)$ of the $\mathrm{AC}$ unit and heat pump (cooling mode) is the same and estimated by the following equation that is a curve fit to the manufacturer's data (Mitsubishi, 2014):

$$
C O P_{\text {cool }}=-0.1549 \cdot T_{o}+11.086
$$

where $T_{o}$ is outside air dry bulb temperature $\left({ }^{\circ} \mathrm{C}\right)$.

Similarly, the COP of the heat pump in heating mode is estimated by the following equation that is a curve fit to the manufacturer's data (Mitsubishi, 2014):

$$
C O P_{\text {heat }}=0.0416 \cdot T_{o_{-} w b}+4.4108
$$

where $T_{O_{-} w b}$ is outside air wet bulb temperature $\left({ }^{\circ} \mathrm{C}\right)$.

When the outdoor air temperature is below the heat pump's operating range, electric resistance heating is used where the COP equals to one. The annual electricity consumption for cooling $\left(E_{\text {cool_yr }}\right.$ in $\left.\mathrm{kWh} \mathrm{yr}^{-1}\right)$ is given by:

$$
E_{\text {cool_yr }}=\sum_{\Delta t=0}^{\frac{365 \cdot 24}{\Delta t}}\left(\left[\frac{Q_{\text {cool }} \cdot \Delta t}{3600}\right] / C O P_{\text {cool }}\right)
$$

where the factor 3600 serves to convert units hr to s.

The annual electricity consumption for heating $\left(E_{\text {heat_yr }}\right.$ in

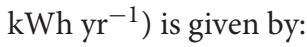

$$
E_{\text {heat_yr }}=\sum_{\Delta t=0}^{\frac{365 \cdot 24}{\Delta t}}\left(\left[\frac{Q_{\text {heat }} \cdot \Delta t}{3600}\right] / \text { COP }_{\text {heat }}\right)
$$

\section{Electricity Consumption for DHW Heating}

The existing house uses electric resistance water heating whereas the new house employs an electric $\mathrm{CO}_{2}$ heat pump. The schedule provided by NRCC (National Research Council of Canada) (2015) for DHW supply in new homes was adopted for this study (hot water consumption of $140 \mathrm{~L} \mathrm{day}^{-1}$ ) and given in Table 4. Since the existing house does not employ low flow faucets, the DHW consumption schedule was increased by $25 \%$ to be in agreement with typical house DWH energy use. The hourly water use $\left(v_{D H W}\right.$ in $\left.\mathrm{L} \mathrm{hr}^{-1}\right)$ was converted to thermal energy consumption $\left(Q_{D H W \_h r}\right.$ in $\left.\mathrm{kJ} \mathrm{hr}^{-1}\right)$ using the water mains temperature provided by TRNSYS $\left(T_{\text {mains }}\right)$. The hourly energy consumption for DHW is calculated by:

$$
Q_{D H W}=v_{D H W} \cdot \rho_{w} \cdot c_{P_{-} w} \cdot\left(T_{D W H}-T_{\text {mains }}\right) / 3600
$$

where

$\rho_{w}$ is the density of water $\left(\mathrm{kg} \mathrm{m}^{-3}\right)$

$c_{p_{-} w}$ is specific heat of water at constant pressure $(\mathrm{kJ}$ $\mathrm{kg}^{-1 \circ} \mathrm{C}^{-1}$ )

$T_{D W H}$ is the DHW supply temperature $\left({ }^{\circ} \mathrm{C}\right)$

the factor 3600 serves to convert units hr to s.

The COP of the $\mathrm{CO}_{2}$ heat pump is estimated by the following equation that is a curve fit to the manufacturer's data (Miles et al., 2017):

$$
\begin{array}{r}
C O P_{C O 2 \_h p}=-4 \cdot 10^{-5} \cdot T_{o}{ }^{3}-0.0005 \\
\cdot T_{o}{ }^{2}+0.077 \cdot T_{o}+3.2676
\end{array}
$$

When the outdoor air temperature is below the heat pump's operating range, electric resistance heating is used where the $\mathrm{COP}$ equals to one. The annual electricity consumption for $\mathrm{DWH}$

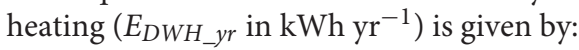

$$
E_{D W H_{-} y r}=\sum_{\Delta t=0}^{\frac{365 \cdot 24}{\Delta t}}\left(\left[\frac{Q_{D W H} \cdot \Delta t}{3600}\right] / \mathrm{COP}_{\mathrm{CO} \_\_h}\right)
$$

\section{RESULTS AND DISCUSSION \\ Model Plausibility Check}

Since the level of thermal insulation for the existing house is not precisely known, the model was calibrated by adjusting the envelope thermal insulation level to obtain a best fit between the model calculations and the annual use of typical detached houses given by Hydro-Québec (2020). It was found that reducing the thermal insulation levels to $35 \%$ below the Novoclimat values provided good agreement between the simulated and 
TABLE 5 | Comparison of typical and simulated detached house energy consumption.

\begin{tabular}{lccc}
\hline Electricity end use & Fraction for typical & \multicolumn{2}{c}{ Electricity use (kWh $\mathbf{~ r ~}^{-1} \mathbf{)}$} \\
\cline { 3 - 4 } & & Typical house & Modeled \\
\hline Heating & $55 \%$ & 13,200 & 14,097 \\
Cooling & $3 \%$ & 720 & 535 \\
DHW & $16 \%$ & 3,840 & 3,838 \\
Plug loads & $26 \%$ & 6,240 & 4,088 \\
Total & $100 \%$ & 24,000 & 22,557 \\
\hline
\end{tabular}

typical measured electricity consumption for heating and cooling (Table 5). The selected thermal insulation values were also sufficiently close to those reported by Parekh (2005) using data gathered from various surveys of housing stock in Canada. The simulated electricity consumption for DWH heating (based on the NRCC water draw schedule) was nearly identical to the typical house values. The plug loads (which includes lighting, appliances, electronics, and others) have been purposely reduced for the modeled house to reflect the use of newer devices and equipment that may have been recently upgraded (George, 2016). This allows for fairer comparison between the existing and new house, with the focus on evaluating the impact of thermal energy performance. Overall, the modeled house consumes 6\% less

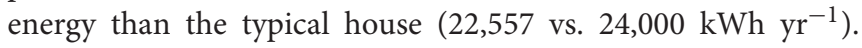
Most of this difference is associated with the decision to reduce plug loads.

\section{Impact of Energy Efficiency Measures}

This section aims to quantify the effect of applying efficiency measures on the existing house ("existing retrofitted" scenario). Efficiency upgrades that lower the space and DWH heating will have the highest impact on total energy consumption because together they represent $\sim 71 \%$ of the house's energy needs (Hydro-Québec, 2020). Table 6 presents the values and percent change of electricity consumption (divided by end use) that can be achieved compared to the typical base case house. Efficiency measures for the plug loads are not considered. The energy efficiency measures were implemented sequentially and the impact on energy consumption for each one is described below:

- The use of a reversible heat pump provided the highest potential for energy savings and decreased heating electricity consumption by $58 \%$ and total electricity consumption by $37 \%$. The heat pump did not affect cooling because the AC unit's COP was assumed to be equal to that of the heat pump.

- Improving thermal insulation to Novoclimat standards decreased heating electricity consumption by another $7 \%$ (heating electricity use is now $65 \%$ below the base case) and increased cooling electricity consumption by $11 \%$ above the base case. This caused the total electricity consumption to decrease by another $4 \%$ (total electricity use is now $41 \%$ below the base case). Therefore, improving the thermal insulation has opposite effects on heating and cooling electricity use,

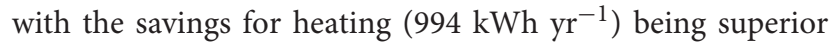

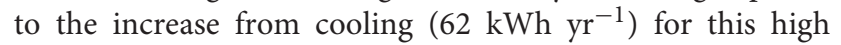
latitude location.

- Upgrading the windows to double glazed argon filled with low-e coating decreased heating electricity consumption by another $7 \%$ (heating electricity use is now $72 \%$ below the base case) and reduced cooling electricity use to $5 \%$ below the base case (change of $16 \%$ compared to the previous case where an increase in cooling was observed). Improving the windows caused the total electricity use to decrease by another $4 \%$ (total electricity use is now $45 \%$ below the base case).

- The use of reflective movable blinds did not impact heating energy use because they are only activated in the cooling season. They provided another 15\% decrease in cooling electricity consumption (cooling electricity use is now $20 \%$ below the base case). Since cooling represents a small fraction of total energy use, the impact on total electricity consumption was only a $1 \%$ reduction (total electricity use is now $46 \%$ below the base case).

- Improving the building airtightness and adding mechanical ventilation with ERV decreased heating electricity consumption by another $7 \%$ (heating electricity use is now $79 \%$ below the base case), increased cooling electricity consumption by an additional $2 \%$ compared to the previous case because more warm outside air needs to be cooled (cooling electricity use is now $18 \%$ below the base case) and reduced total electricity consumption by another $4 \%$ (total electricity use is now $50 \%$ below the base case).

- The use of low flow faucets reduces DHW consumption, leading to a $20 \%$ decrease in electricity consumption for DHW heating compared to the base case or another $3 \%$ reduction in total electricity use (total electricity use is now $53 \%$ below the base case).

- $\mathrm{A} \mathrm{CO}_{2} \mathrm{DHW}$ heat pump decreased the electricity consumed for DHW heating by another 56\% (electricity use for DWH heating is now $76 \%$ below the base case). This caused the total electricity consumption to decrease by another $10 \%$ (total electricity use is now $63 \%$ below the base case).

- In total, the combined effect of these energy efficiency measures caused the space heating, space cooling, DWH heating and total electricity consumption to decrease by 79 , 18,76 , and $63 \%$, respectively.

\section{Thermal Energy Consumption}

To evaluate the impact of densification on energy use, a comparison of thermal energy must be performed without considering the type of HVAC equipment used. Table 7 provides a comparison of the thermal energy consumption of the existing house (with all the above energy efficiency measures applied) and the new houses. The energy consumption was nearly identical $(<0.2 \%)$ for each of the new houses. Since the basement is smaller for the new houses, the results are also presented for the case where heating energy for the existing basement is reduced by $40 \%$ to provide a fairer comparison (approximate adjustment). The new house consumes 10, 46 (adjusted), and $65 \%$ less thermal energy for heating that the existing house for the living area, basement and garage, respectively. The heating 
TABLE 6 | Impact of sequential implementation of energy efficiency measures on electricity consumption.

\begin{tabular}{|c|c|c|c|c|c|}
\hline Energy efficiency retrofit & \multicolumn{5}{|c|}{ Electricity consumption $\left(\mathrm{kWh} \mathrm{yr}^{-1}\right)$} \\
\hline Heat pump for space heating/cooling & 5,869 & 536 & 3,838 & 4,088 & 14,331 \\
\hline$\%$ change & $-58 \%$ & $0 \%$ & $0 \%$ & $0 \%$ & $-37 \%$ \\
\hline Improve insulation & 4,875 & 598 & 3,838 & 4,088 & 13,399 \\
\hline$\%$ change & $-72 \%$ & $-5 \%$ & $0 \%$ & $0 \%$ & $-45 \%$ \\
\hline Movable blinds & 3,891 & 428 & 3,838 & 4,088 & 12,245 \\
\hline$\%$ change & $-72 \%$ & $-20 \%$ & $0 \%$ & $0 \%$ & $-46 \%$ \\
\hline Improve airtightness and add ERV & 2,995 & 438 & 3,838 & 4,088 & 11,358 \\
\hline$\%$ change & $-79 \%$ & $-18 \%$ & $0 \%$ & $0 \%$ & $-50 \%$ \\
\hline$\%$ change & $-79 \%$ & $-18 \%$ & $-76 \%$ & $0 \%$ & $-63 \%$ \\
\hline
\end{tabular}

TABLE 7 | Thermal energy consumption of the retrofitted existing and new houses.

\begin{tabular}{|c|c|c|c|c|}
\hline Operation & Thermal zone & \multicolumn{2}{|c|}{ Annual thermal energy consumption (kWh $\left.\mathrm{yr}^{-1}\right)$} & $\%$ change \\
\hline \multirow{3}{*}{ Heating } & Basement & $791(475)^{\star}$ & 258 & $-67 \%(-46 \%)$ \\
\hline & Garage & 1,004 & 352 & $-65 \%$ \\
\hline & Total & 6,661 (6,345) & 4,982 & $-25 \%(-21 \%)$ \\
\hline
\end{tabular}

*Approximate adjustment values considering that the garage heating energy use is reduced by $40 \%$ are in parenthesis.

energy was reduced by $\sim 21 \%$ (adjusted) for the entire house. This reduction occurs due to a combination of effects related to adopting a more compact design (e.g., two stories instead of one, adjacency to attached house, geometry). The living area of the new house required 15\% more cooling that the existing house mainly because it has less external surface area and less area in contact with a relatively cooler basement. Overall, the denser new house consumed $8 \%$ less thermal energy (adjusted) because the requirements for heating outweighed the increase in cooling for this geographic location.

\section{Electricity Consumption}

Table 8 presents the electricity consumption by end use for the existing and new houses. The new house consumed $83 \%$

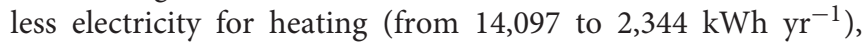

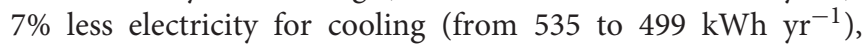
and $76 \%$ less electricity for DHW heating (from 3,838 to

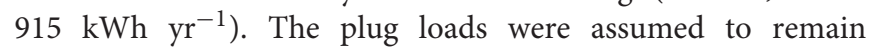
the same. Overall, implementing the new double density design reduced electricity consumption by $65 \%$ (from 22,557

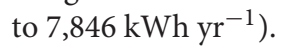

TABLE 8 | Electricity consumption by end use for the existing and new houses.

\begin{tabular}{lccc}
\hline \multirow{2}{*}{ End use } & \multicolumn{3}{c}{ Annual electricity consumption $\left(\mathbf{k W h ~} \mathbf{y r}^{-1}\right)$} \\
\cline { 2 - 4 } & Existing house & Per new house & \% change \\
\hline Heating & 14,097 & 2,344 & $-83 \%$ \\
Cooling & 535 & 499 & $-7 \%$ \\
DHW & 3,838 & 915 & $-76 \%$ \\
Plug loads & 4,088 & 4,088 & $0 \%$ \\
Total & 22,557 & 7,846 & $-65 \%$ \\
\hline
\end{tabular}

\section{Photovoltaic Electricity Generation}

Renewable electricity can be produced on-site by integrating a PV system with the building envelope. Table 9 provides the performance of such a system where PV modules are applied to the south facing roof of the existing house (building applied PV) and new houses (ideally building-integrated PV to replace the need for conventional cladding). Since the existing house has more than double the roof surface area covered by PV $\left(97.7 \mathrm{~m}^{2}\right)$ 
TABLE 9 | Energy performance of the PV system installed on the south facing roof.

\begin{tabular}{lccc}
\hline Result & Existing house & Existing retrofitted & Per new house \\
\hline $\begin{array}{l}\text { Electricity consumption } \\
\left(\mathrm{kWh} \mathrm{yr}^{-1} \text { ) }\right.\end{array}$ & 22,557 & 8,435 & 7,846 \\
$\begin{array}{l}\text { Roof area covered by } \\
\text { PV }\left(\mathrm{m}^{2}\right)\end{array}$ & 0 & 97.7 & 46.1 \\
$\begin{array}{l}\text { PV peak power at STC } \\
\text { (kW) }\end{array}$ & - & 20.7 & 9.8 \\
$\begin{array}{l}\text { PV electricity } \\
\left.\text { generation (kWh yr }{ }^{-1}\right)\end{array}$ & - & 31,232 & 14,793 \\
$\begin{array}{l}\text { Portion of house } \\
\text { electricity directly from }\end{array}$ & - & $41 \%$ & $41 \%$ \\
$\begin{array}{l}\text { PV } \\
\text { Portion of PV electricity } \\
\text { available for on-site } \\
\text { storage or export }\end{array}$ & - & & \\
\hline
\end{tabular}

TABLE 10 | Impact of house orientation on PV electricity generation.

\begin{tabular}{llc}
\hline House orientation & PV location & Electricity generation $\mathbf{( k W h ~} \mathbf{~ r}^{-\mathbf{1}} \mathbf{)}$ \\
\hline $\begin{array}{l}\text { Front of house facing } \\
\text { south }\end{array}$ & South facing roof & 14,793 \\
& North facing roof & 7,218 \\
& Total & 22,011 \\
Front of house facing & East facing roof & 11,280 \\
east & & \\
& West facing roof & 11,386 \\
& Total & 22,666 \\
\hline
\end{tabular}

than each of the new houses $\left(46.1 \mathrm{~m}^{2}\right)$, it generated significantly more electricity $\left(31,232 \mathrm{kWh} \mathrm{yr}^{-1}\right)$ than each of the new houses

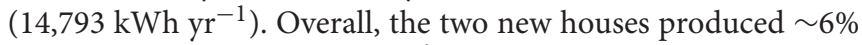
less electricity $\left(29,586 \mathrm{kWh} \mathrm{yr}^{-1}\right)$ than the existing house $(31,232$

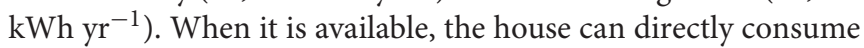
the generated solar electricity instead of obtaining it from the grid. Annually, it was found that $41 \%$ of the existing and new house's electricity consumption can be obtained directly from the PV system (no storage). However, during the day, the electricity generation often exceeds the energy requirements of the house. The portion of excess electricity represented 89 and $78 \%$ of the total electricity produced by the PV system for the existing retrofitted and new houses, respectively. Therefore, a significant amount of energy produced by energy efficient solar houses would be available for further valorization.

A comparison of PV electricity generation using both roof surfaces and for two orientations (front of the house faces south and east) for one of the new houses is given in Table 10. The total electricity generated is similar for both orientations (3\% higher for the east facing orientation). When the house faces south, the south facing roof produces more than twice the amount of energy $\left(14,793 \mathrm{kWh} \mathrm{yr}^{-1}\right)$ than the north facing roof $\left(7,218 \mathrm{kWh} \mathrm{yr}^{-1}\right)$. When the house is rotated by $90^{\circ}$ counterclockwise, both roof surfaces produce similar quantities of electricity.
TABLE 11 | Impact of house orientation on energy performance.

\begin{tabular}{lccc}
\hline End use & \multicolumn{2}{c}{$\begin{array}{c}\text { Annual electricity consumption } \\
\text { (kWh } \mathbf{~ r}^{-1} \mathbf{)}\end{array}$} & \% change \\
\cline { 2 - 3 } & $\begin{array}{c}\text { Front of house } \\
\text { facing south }\end{array}$ & $\begin{array}{c}\text { Front of house } \\
\text { facing east }\end{array}$ & \\
\hline Heating & 2,344 & 2,541 & $8 \%$ \\
Cooling & 499 & 623 & $25 \%$ \\
DHW & 915 & 915 & $0 \%$ \\
Plug loads & 4,088 & 4,088 & $0 \%$ \\
Total & 7,347 & 7,755 & $6 \%$ \\
PV electricity & 22,011 & 22,666 & $3 \%$ \\
Net electricity use & $-14,664$ & $-14,911$ & $2 \%$ \\
\hline
\end{tabular}

TABLE 12 | Comparison of the energy performance at the land lot level.

\begin{tabular}{lll}
\hline & Existing house & Two new houses \\
\hline $\begin{array}{l}\text { Number of occupants on } \\
\text { land lot (pers) }\end{array}$ & 4 & 8 \\
$\begin{array}{l}\text { Electricity consumption } \\
\text { (kWh yr }{ }^{-1} \text { ) }\end{array}$ & 22,557 & 15,691 \\
$\begin{array}{l}\text { PV electricity generation } \\
\text { (kWh } \mathrm{yr}^{-1} \text { ) }\end{array}$ & - & 44,022 \\
$\begin{array}{l}\text { Portion of house electricity } \\
\text { directly from PV }\end{array}$ & - & $44 \%$ \\
$\begin{array}{l}\text { Portion of PV electricity } \\
\text { available for on-site storage } \\
\text { or export }\end{array}$ & - & $84 \%$ \\
$\begin{array}{l}\text { Net electricity use } \\
\text { (kWh yr }\end{array}$ & & \\
Net electricity use per & & $-28,331$ \\
occupant (kWh yr & & \\
\hline
\end{tabular}

Table 11 presents the impact of house orientation on energy performance of one of the new houses. Rotating the house by $90^{\circ}$ counterclockwise caused the heating, cooling, and total electricity consumption to increase by 8,25 , and $6 \%$, respectively. The large increase in cooling is likely a result of the patio door (that does not have movable shades) which now faces east (previously faced north) causing more solar gains. Meanwhile, electricity generation increased by $3 \%$, counterbalancing a portion of the higher electricity demand caused by the different orientation. The net electricity use is similar for both orientations ( $2 \%$ more when the front of the house faces east) and carries a negative value because the houses produced nearly three times more energy than it consumes on an annual basis (also known as self-sufficiency ratio).

\section{Energy Performance Comparison}

Table 12 presents a comparison of the overall energy performance for the existing and new houses. The two new houses can accommodate twice the number of occupants (eight instead of four) on the same land lot while transforming the status quo of inefficient houses to high efficiency energy generating houses. The existing house consumed 22,557 
$\mathrm{kWh} \mathrm{yr}^{-1}$ whereas the new houses together consumed $30 \%$ less energy $\left(15,691 \mathrm{kWh} \mathrm{yr}^{-1}\right)$. Meanwhile, when both sides of the roof of the new houses are equipped with BIPV, nearly three times more energy is produced than is consumed. Annually, almost half (44\%) of the house's electricity can be directly supplied by the BIPV roof and $84 \%$ of the generated solar electricity could be available for utilization on-site (e.g., thermal or electrical energy storage) and/or elsewhere (e.g., fed into the grid). The combined effect of adopting a denser energy efficient design with on-site renewable energy production enables occupants to shift from consuming $5,639 \mathrm{kWh} \mathrm{yr}^{-1}$ to producing $3,541 \mathrm{kWh} \mathrm{yr}^{-1}$.

\section{Power Demand Comparison}

Utilities design their baseload and peaking power plants to satisfy the fluctuating demand for electricity. The demand for power is usually greatest in winter for high latitude locations that employ electrified heating such as in Québec. In Ontario, where natural gas is typically used for heating, the peak power demand occurs in summer when electric cooling loads are highest. Peak power supply typically carries a higher cost for utilities due to the initial cost of electric power transmission infrastructure and peaking power plants, which are also usually greenhouse gas (GHG) emissions intensive as they often burn fossil fuels and with lower efficiencies than baseload power plants. Therefore, efforts to reduce and shift the peak power demand profile of buildings can contribute toward lowering the cost, resource utilization, and GHG emissions of existing and new power plant infrastructure.

Figure 3A illustrates the power demand profile for the existing and two new houses in addition to the PV power production on a cold sunny winter day (weather for February 9 shown in Figure 3B). The power demand for the two new houses is similar to the existing house from midnight until noon and was lower afterwards by up to $3 \mathrm{~kW}$. The PV power production quickly exceeds the house's power demand but only for a relatively short period, thereby creating the need for technology capable of rapidly converting a large amount of fluctuating excess power.

\section{Use of Excess Solar Electricity}

This study reports the upper limit of solar electricity that can be produced on a house by using both surfaces of the roof. Additional solar electricity can be generated from the wellexposed façade surfaces of the house or less may be produced for instance by installing BIPV only on the south-facing roof. Economic analysis would be required to determine the most costeffective investment. By covering the entire roof with BIPV, a significant portion (84\%) of the annual solar electricity produced by the new houses cannot be directly consumed to satisfy its instantaneous energy demand and would therefore be available for use elsewhere. The main solutions for the valorization of the excess electricity generated by low energy solar houses are presented below:

Energy export:

- Displace fossil fuel energy use: The excess solar electricity can be used to reduce electricity and thermal energy that is produced from fossil fuels (e.g., displace natural gas consumed by a power plant or boiler).
- Power-to-X: Convert excess electricity to hydrogen via electrolysis. The obtained hydrogen can be injected into the natural gas pipeline, used to produce hydrogen that would otherwise typically be derived from natural gas or to power fuel cell electric vehicles (EV). It may also be converted to liquid fuels (power-to-liquids) or other chemicals (power-to-chemicals).

- Battery EV charging: The excess electricity can be used to charge battery $\mathrm{EV}$, possibly at a discounted price during curtailment periods.

- Export energy to the grid when the grid needs it by utilizing the flexibility in the building demand profile, incentivized by dynamic electric pricing (Athienitis et al., 2020).

On-site energy storage and utilization of the flexibility in the building electricity demand profile:

- Building thermal mass and setpoint modification: This can be achieved by pre-heating/cooling the building's thermal mass (e.g., using radiant concrete slab) to reduce the thermal loads that occur when solar electricity is not being generated and applying predictive control (Athienitis et al., 2020).

- Controlled appliance loads: This consist of powering devices during the periods where excess solar electricity exists (e.g., cloths and dish washing machines).

- Power-to-thermal energy: Heat pumps could operate using excess solar electricity to produce heat, cooling or ice that can be stored (e.g., in water storage tanks) for later use.

- Electrical energy storage: Electrical energy can be stored by electrochemical (e.g., battery, hydrogen, supercapacitor) or mechanical (e.g., flywheel) means.

- EV charging/refueling: A personal battery EV may be charged using the house's excess electricity during the day and may be well-suited for teleworking. Eventually, it may also be possible to produce, store, and refuel a hydrogen EV at home. Moreover, the EVs could provide bi-directional energy flow by supplying backup power to the house.

Long term energy storage:

- Seasonal thermal energy storage: A borehole may be charged with solar thermal heat (mainly during the summer) or freecooled (during the winter) and used as a resilient form of heating in winter or cooling in summer. The Drake Landing Solar Community (DLSC) in Alberta, Canada uses seasonal storage of solar energy to provide at least $90 \%$ of the space heating requirements for the 52 houses that its serves (Sibbitt et al., 2012).

- Seasonal electrical energy storage: The excess solar electricity that is generated in the summer season may be stored as compressed air or hydrogen and converted back into electricity in winter.

\section{Challenges and Opportunities}

Although the energy analysis of land lot densification was conducted for a single location, it is expected that other locations would yield similar outcomes of lowering building energy consumption, producing renewable energy on-site and lowering the amount of land required by humans. Net zero 
A

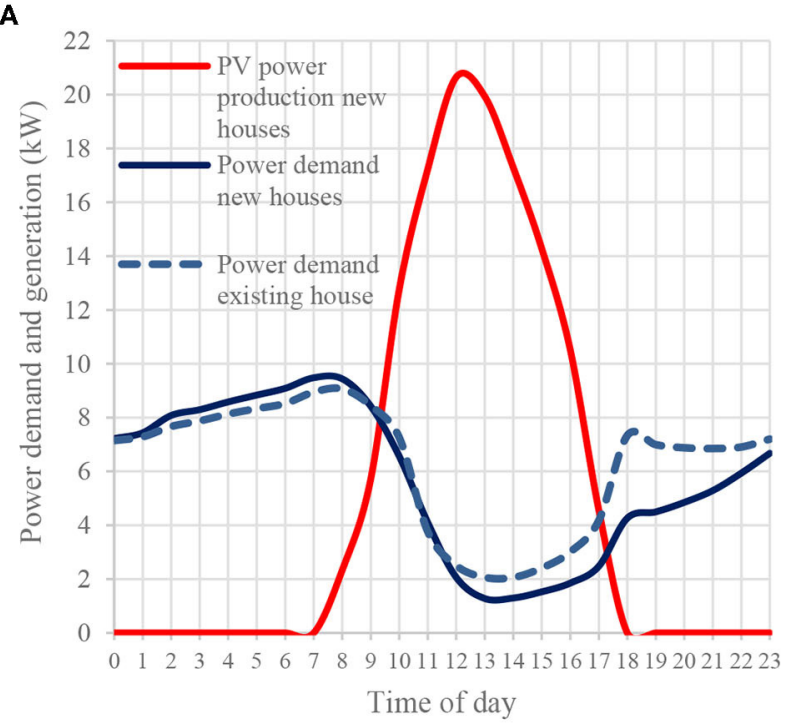

B

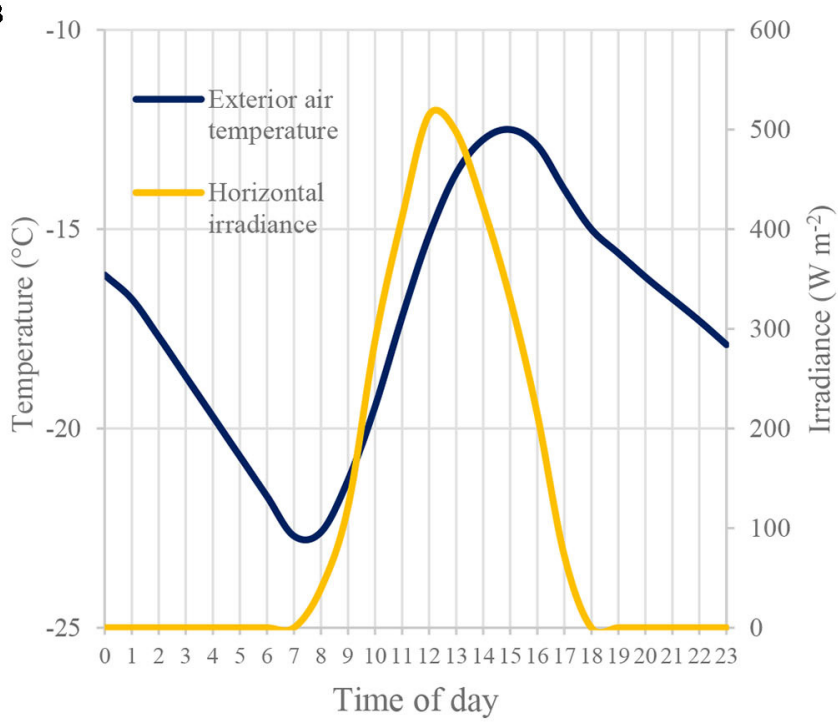

FIGURE 3 | (A) Power demand and solar electricity generation for the existing and two new houses on a cold sunny winter day. (B) Exterior air temperature and horizontal irradiance.

energy is more difficult to achieve at higher latitudes (e.g., northern Canada) due to the high heating load compared to solar energy availability whereas positive energy is likely to be possible throughout the U.S.A. Moreover, this study considered only some of the most promising energy efficiency measures and BIPV for on-site generation. A comparison between various options including economic analysis is out of the scope of this paper. For instance, solar water heating could be an alternative to heat pump water heaters. The relative value of the shared roof space for solar thermal and PV mix would need to be assessed for technology selection.

As humans increasingly strive to decouple from polluting sources of energy, it has become apparent that reducing energy consumption through energy efficiency and behavioral changes should be prioritized. This is mainly due to the higher cost, material resource utilization, and pollution associated with renewable energy plus storage solutions. Densified residential rebuilds provides the dual benefit of making more effective use of available land and energy resources. The results of this paper help to quantify potential energy reductions and on-site generation using currently available technologies and could assist governments to develop policy, incentives, and regulations that can expedite this trend. For instance, the zoning laws could be modified to facilitate the conversion of existing homes to densified counterparts, subsidies could help cover the additional cost of the most promising energy efficiency solutions and feedin-tariffs could improve the economics for installing BIPV.

Utilities will also play an important role in promoting positive energy buildings/districts because they affect the design, operation, and economics of current and future grid infrastructure. For example, large surpluses of solar energy produced from the built environment in the summer could disrupt the economics of existing power plants. A multisector collaborative approach would be useful to effectively transfer excess power and decarbonize elsewhere, such as transportation and industry. Another option includes long term energy storage of summer surplus energy to assist with winter deficits. However, in the short term, this option may only be favorable for remote microgrids such as in Northern Canada due to the high cost of energy storage.

Although redevelopment drastically reduces the consumption of operating and to some extent transportation energy, new construction requires material and human resources that embed significant energy and pollution footprints. Depending on the supplies/materials/equipment selected and countries where they are extracted/processed/manufactured, the time required to recover initial GHG emissions can vary dramatically. For instance, in Québec, building primarily with a low GHG emitting material such as wood and using the excess solar electricity to decarbonize a high GHG emission sector such as transportation would result in a relatively short emissions payback. In contrast, building with carbon intensive materials such as steel or concrete and using the surplus solar electricity to displace relatively clean hydroelectricity would require a much longer period to achieve a payback. Therefore, a life cycle analysis, which considers the environmental impact of the building operation, transportation, and demolition/recycling/construction should be considered when deciding between options. Future work into quantifying the embodied energy and associated pollution of buildings as a function of geographical location would streamline the decision-making process.

\section{CONCLUSION}

This paper demonstrated how residential densification can be an effective way to reduce the energy and land required for 
inhabitants in an urban setting. In this study, the energy performance of a typical aging single family home was compared to a densification scenario where two energy efficient homes of equal living area and equipped with an energy generating BIPV roof are built on the same land lot located in the suburbs of Montreal, Québec, Canada $\left(45.5^{\circ} \mathrm{N}\right.$, mid-latitude, 4,457 heating degree-days).

The two new houses can accommodate twice the number of occupants on the same land lot and can transform the status quo of inefficient houses to high efficiency energy generating houses. Of the various energy efficiency measures that were selected, the use of heat pumps for space and water heating achieved the greatest reduction in energy use. When comparing the case where the existing house is retrofitted with the same efficiency measures as the new house, it was found that a denser design decreased the thermal energy required for heating by $21 \%$ and increased thermal energy for cooling by $15 \%$, leading to an overall reduction in thermal energy use of $\sim 8 \%$. Each of the new houses consumed $65 \%$ less electricity than the existing house (from

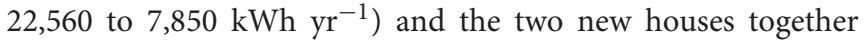
consumed $30 \%$ less energy than its existing counterpart. The BIPV roof produced nearly three times more energy $(44,000 \mathrm{kWh}$ $\mathrm{yr}^{-1}$ ) than consumed by the two new houses $\left(15,700 \mathrm{kWh} \mathrm{yr}^{-1}\right)$. Rotating the houses by $90^{\circ}$ counterclockwise was found to have a small impact on the energy consumption $(+6 \%)$ and generation $(+3 \%)$. Annually, nearly half (44\%) of the house's electricity can be directly supplied by the BIPV roof. A significant portion of the annual solar electricity generation (84\%), which cannot be directly utilized by the houses, may be stored on-site to increase self-consumption (e.g., operate heat pumps using excess power to heat/cool/freeze a liquid and store it for later use) and/or used for decarbonization elsewhere (e.g., feed excess electricity into the grid to displace fossil fuel power generation, electrolysis to produce hydrogen fuel for transportation). The peak power demand, which occurs on a cold winter day, was lower for

\section{REFERENCES}

Alshehri, F., Beck, S., Ingham, D., Ma, L., and Pourkashanian, M. (2019). Technoeconomic analysis of ground and air source heat pumps in hot dry climates. J. Buil. Eng. 26:100825. doi: 10.1016/j.jobe.2019.100825

ASHRAE (2019). Standard 62.2-2019. Ventilation and Acceptable Indoor Air Quality in Residential Buildings, Atlanta: American National Standards Institute.

Aste, N., Buzzetti, M., Del Pero, C., and Leonforte, F. (2018). Glazing's techno-economic performance: a comparison of window features in office buildings in different climates. Energy Build. 159, 123-135. doi: 10.1016/j.enbuild.2017.10.088

Athienitis, A. (1998). Building Thermal Analysis. Cambridge, MA: MathSoft Inc.

Athienitis, A. K., Bambara, J., O’Neill, B., and Faille, J. (2011). A prototype photovoltaic/thermal system integrated with transpired collector. Solar Energy 85, 139-153. doi: 10.1016/j.solener.2010.10.008

Athienitis, A. K., Dumont, E., Morovat, N., Lavigne, K., and Date, J. (2020). "Development of a dynamic energy flexibility index for buildings and their interaction with smart grids," in Proceedings of ACEEE Summer Study 2020 Conference on Energy Efficiency in Buildings (Pacific Grove, CA).

Brown, M. A., and Logan, E. (2008). The Residential Energy and Carbon Footprints of the 100 Largest US Metropolitan Areas. Atlanta, GA: Georgia Institute of Technology. the two new houses than the existing house and could be further reduced by employing power-to-heat plus thermal energy storage strategies together with predictive control. Overall, the combined effect of a denser, energy efficient construction with on-site renewable energy production enables occupants to shift

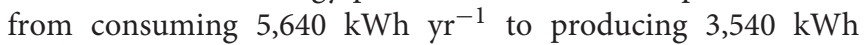
$\mathrm{yr}^{-1}$. The combination of urbanization, a growing population and an aging building stock provides a unique opportunity to retrofit existing communities into positive energy districts. New policy, incentives and regulations regarding the redevelopment of densified net-zero ready homes could be instrumental for this trend to gain momentum.

\section{DATA AVAILABILITY STATEMENT}

The original contributions presented in the study are included in the article/supplementary material, further inquiries can be directed to the corresponding author.

\section{AUTHOR CONTRIBUTIONS}

JB carried out the work and wrote the paper. UE and AA did proofreading and corrections. All authors contributed to the article and approved the submitted version.

\section{FUNDING}

The work was partially supported by NSERC research grants of AA and the Canada Excellence Research Chair (CERC) on smart, sustainable and resilient cities and communities held by UE.

\section{ACKNOWLEDGMENTS}

The authors acknowledge the financial support of the Concordia University Horizon Postdoctoral Fellowship to JB.
Bucking, S., Athienitis, A., Zmeureanu, R., O’Brien, W., and Doiron, M. (2010). "Design optimization methodology for a near net zero energy demonstration home," in EuroSun (Graz).

Capozzoli, A., Mechri, H. E., and Corrado, V. (2009). "Impacts of architectural design choices on building energy performance applications of uncertainty and sensitivity techniques," in Proceedings of the Eleventh International Building Performance Simulation Association Conference (IBPSA) (Glasgow).

Crawley, D. B., Hand, J. W., Kummert, M., and Griffith, B. T. (2008). Contrasting the capabilities of building performance simulation programs. Build. Environ. 43, 661-673. doi: 10.1016/j.buildenv.2006.10.027

Dobos, A. P. (2014). PVWatts Version 5 Manual (No. NREL/TP-6A20-62641). Golden, CO: National Renewable Energy Laboratory.

DOE (2015). WINDOW 7.3. Washington, DC: Department of energy. USA. Available online at: https://windows.lbl.gov/software/window/7/index_7_3_4. html (accessed December 12, 2019).

Ekström, T., and Blomsterberg, A. (2016). Renovation of Swedish single-family houses to passive house standard-analyses of energy savings potential. Energy Procedia 96, 134-145. doi: 10.1016/j.egypro.2016.09.115

Englart, S., and Jedlikowski, A. (2019). The influence of different water efficiency ratings of taps and mixers on energy and water consumption in buildings. SN Appl. Sci. 1:525. doi: 10.1007/s42452-019-0539-8

Fantozzi, F., Le Bail, L., Leccese, F., Rocca, M., and Salvadori, G. (2017). General lighting in offices building: techno-economic considerations on the 
fluorescent tubes replacement with LED tubes. Int. J. Eng. Technol. Innov. 7, 143-156.

Gebhart, B. (1961). Surface temperature calculations in radiant surroundings of arbitrary complexity-for gray, diffuse radiation. Int. J. Heat Mass Transfer 3, 341-346. doi: 10.1016/0017-9310(61) 90048-5

Gebhart, B. (1971). Heat Transfer, 2nd Edn. New York, NY: McGraw-Hill.

George, D. (2016). New profiles of occupancy driven appliance, lighting, plug loads, and hot water use for residential sector energy demand modeling (master's thesis). Dalhousie University, Halifax, NS, Canada.

Granadeiro, V., Duarte, J. P., Correia, J. R., and Leal, V. M. (2013). Building envelope shape design in early stages of the design process: integrating architectural design systems and energy simulation. Autom. Constr. 32, 196-209. doi: 10.1016/j.autcon.2012.12.003

Hachem, C., Athienitis, A., and Fazio, P. (2011). Investigation of solar potential of housing units in different neighborhood designs. Energy Buil. 43, 2262-2273. doi: 10.1016/j.enbuild.2011.05.008

Hamdhan, I. N., and Clarke, B. G. (2010). "Determination of thermal conductivity of coarse and fine sand soils," in Proceedings of World Geothermal Congress (Bali), 1-7.

Han, Y., Liu, X., and Chang, L. (2014). Comparison of software for building energy simulation. J. Chem. Pharm. Res. 6, 467-471.

Heidari, M., and Patel, M. (2020). Stock modelling and cost-effectiveness analysis of energy-efficient household electronic appliances in Switzerland. Energy Effic. 13, 571-596. doi: 10.1007/s12053-020-09843-x

Holden, E., and Norland, I. T. (2005). Three challenges for the compact city as a sustainable urban form: household consumption of energy and transport in eight residential areas in the greater Oslo region. Urban Stud. 42, 2145-2166. doi: 10.1080/00420980500332064

Hydro-Québec (2020). Available online at: https://www.hydroquebec.com/ residential/customer-space/electricity-use/tools/electricity-use.html (accessed March 15, 2020)

International Electrotechnical Commission (IEC) (2011). Photovoltaic Module Performance Testing and Energy Rating-Part 1: Irradiance and Temperature Performance Measurements and Power Rating IEC 61853-1. Geneva: International Electrotechnical Commission.

Jinko Solar (2020). Eagle 78 TR G4 (module JKM475M-7RL3-TV-Q). Available online at: https://y19jx2zo8mb2zyqyo1njsh26-wpengine.netdna-ssl.com/ wp-content/uploads/2020/07/JKM455-475M-7RL3-V-D2-US.pdf (accessed January 21, 2020).

Klein, S. A., Duffie, J. A., Mitchell, J. C., Kummer, J. P., Thornton, J. W., Bradley, D. E., et al. (2014). TRNSYS 17. Volume 4. Mathematical Reference. Madison, WI: Solar Energy Laboratory, University of Wisconsin-Madison.

Kontokosta, C. E. (2012). "Predicting building energy efficiency using New York City benchmarking data," in Proceedings of the 2012 ACEEE Summer Study on Energy Efficiency in Buildings (American Council for an Energy-Efficient Economy) (Washington, DC).

Kunwar, N. (2018). Automated venetian blinds and lighting integrated into office Building Automation Systems: full-scale testing and economic analysis (master's thesis). Iowa State University, Ames, IA, United States.

Liu, S., Li, Z., Dai, B., Zhong, Z., Li, H., Song, M., et al. (2019). Energetic, economic, and environmental analysis of air source transcritical CO2 heat pump system for residential heating in China. Appl. Therm. Eng. 148, 1425-1439. doi: 10.1016/j.applthermaleng.2018. 08.061

McAdams, W. H. (1959). Heat Transmission, 3rd Edn. New York, NY: McGrawHill.

Miles, J., Ito, M., and Hale, D. (2017). Sanden $\mathrm{SANCO}_{2}$. Heat Pump Water Heater Technical Information. Plymouth, MI: Sanden International (USA), Inc.

Minetto, S., Cecchinato, L., Brignoli, R., Marinetti, S., and Rossetti, A. (2016). Water-side reversible $\mathrm{CO} 2$ heat pump for residential application. Int. J. Refrig. 63, 237-250. doi: 10.1016/j.ijrefrig.2015.12.015

Mitalas, G. P., and Arseneault, J. G. (1972). FORTRAN IV program to calculate z-transfer functions for the calculation of transient heat transfer through walls and roofs. Ottawa, ON: Division of National Research Council of Canada.
Mitsubishi (2014). Mitsubishi Electric Corporation. Service Manual. Split-type Air Conditioners. No. OBH684. Revised edition D. Chiyoda-ku, Mitsubishi Electric Corporation.

Mohajeri, N., Upadhyay, G., Gudmundsson, A., Assouline, D., Kämpf, J., and Scartezzini, J. L. (2016). Effects of urban compactness on solar energy potential. Ren. Energy 93, 469-482. doi: 10.1016/j.renene.2016. 02.053

Mohamed, M. M. (2020). Optimal thermal insulation thickness in isolated airconditioned buildings and economic analysis. J. Electron. Cool. Therm. Control 9:23. doi: $10.4236 /$ jectc. 2020.92002

Natural Resources Canada (2020). National Energy Use Database. Available online at: https://oee.nrcan.gc.ca/corporate/statistics/neud/dpa/data_e/databases.cfm (accessed July 11, 2020).

Nemet, G. F. (2009). Net radiative forcing from widespread deployment of photovoltaics. Environ. Sci. Technol. 43, 2173-2178. doi: 10.1021/es80 $1747 \mathrm{c}$

Norman, J., MacLean, H. L., and Kennedy, C. A. (2006). Comparing high and low residential density: life-cycle analysis of energy use and greenhouse gas emissions. J. Urban Plan. Dev. 132, 10-21. doi: 10.1061/(ASCE)0733-9488(2006)132:1(10)

Novoclimat (2003). General Technical Requirements. Quebec: Québec Energy Efficiency Agency.

NRCC (National Research Council of Canada) (2015). National Building Code of Canada. Ottawa, ON: National Research Council Canada.

O'Brien, W., Kennedy, C., Athienitis, A., and Kesik, T. (2009). The relationship between personal net energy use and the urban density of solar buildings. Environ. Plan. B 37, 1002-1021. doi: 10.1068/b36030

Parekh, A. (2005). "Development of archetypes of building characteristics libraries for simplified energy use evaluation of houses," in Proceedings of the Ninth International Building Performance Simulation Association Conference (IBPSA) (Montreal, QC).

Perez, R., Stewart, R., Seals, R., and Guertin, T. (1988). The Development and Verification of the Perez Diffuse Radiation Model (No. SAND-88-7030). Sandia National Labs., Albuquerque, NM; State Univ. of New York, Albany, NY. Atmospheric Sciences Research Center.

Psimopoulos, E., Bee, E., Widén, J., and Bales, C. (2019). Techno-economic analysis of control algorithms for an exhaust air heat pump system for detached houses coupled to a photovoltaic system. Appl. Energy 249, 355-367. doi: 10.1016/j.apenergy.2019.04.080

Quan, J. (2016). Density and energy performance of solar powered buildings in the urban context (Doctoral dissertation). Georgia Institute of Technology, Atlanta, GA, United States.

RETScreen (2013). Clean Energy Project Analysis Software. Version 4. Ottawa, ON: Ministry of Natural Resources.

Sibbitt, B., McClenahan, D., Djebbar, R., Thornton, J., Wong, B., Carriere, J., et al. (2012). The performance of a high solar fraction seasonal storage district heating system-five years of operation. Energy Procedia 30, 856-865. doi: 10.1016/j.egypro.2012.11.097

Skoplaki, E., and Palyvos, J. A. (2009). On the temperature dependence of photovoltaic module electrical performance. a review of efficiency/power correlations. Solar Energy 83, 614-624. doi: 10.1016/j.solener.2008.10.008

Steemers, K. (2003). Energy and the city: density, buildings, and transport. Energy Build. 35, 3-14. doi: 10.1016/S0378-7788(02)00075-0

Stephenson, D. G., and Mitalas, G. P. (1971). "Calculation of heat conduction transfer functions for multi-layer slabs," in ASHRAE Annual Meeting (August 22-25) (Washington, DC).

Touloupaki, E., and Theodosiou, T. (2017). Optimization of building form to minimize energy consumption through parametric modelling. Procedia Environ. Sci. 38, 509-514. doi: 10.1016/j.proenv.2017.03.114

TRNSYS 17 (2005). Multizone Building Modeling with Type56 and TRNBuild. Madison, WI: Solar Energy Laboratory, University of Wisconsin. Available online at: http://sel.me.wisc.edu/trnsys; http://www.trnsys.de (accessed December 12, 2019).

TRNSYS 17 (2014). Mathematical Reference. Madison, WI: Solar Energy Laboratory. University of Wisconsin. Available online at: http://sel.me.wisc. edu/trnsys (accessed December 12, 2019). 
Veitch, J. A. (2008). "Connecting the building sciences and health sciences in Canada: research gaps,". in Proceedings of the First Canadian Building and Health Sciences Workshop (Montreal, QC), 93-105.

Conflict of Interest: The authors declare that the research was conducted in the absence of any commercial or financial relationships that could be construed as a potential conflict of interest.
Copyright (๑) 2021 Bambara, Athienitis and Eicker. This is an open-access article distributed under the terms of the Creative Commons Attribution License (CC BY). The use, distribution or reproduction in other forums is permitted, provided the original author(s) and the copyright owner(s) are credited and that the original publication in this journal is cited, in accordance with accepted academic practice. No use, distribution or reproduction is permitted which does not comply with these terms. 